\title{
GULLIES, GOOGLE EARTH AND THE GREAT BARRIER REEF: A REMOTE SENSING METHODOLOGY FOR MAPPING GULLIES OVER EXTENSIVE AREAS
}

\author{
U. Gilad, R. Denham and D. Tindall
}

Remote Sensing Centre, Queensland Dept. of Environment and Resource Management, ESP, GPO Box 2454, Brisbane, QLD, 4001, Australia - (uri.gilad, robert.denham, dan.tindall)@derm.qld.gov.au

KEY WORDS: Environment, Geomorphology, Mapping, GIS, Prediction, Modelling, Imagery

\begin{abstract}
:
Recent work suggests that gully erosion is the main contributor of sediments to the Great Barrier Reef, Australia. The objectives of this study were to identify the location of gullies as well as the landscape characteristics associated with gully presence in the Burdekin Catchment. Data were collected by random sampling using Google Earth. A spatial-statistical analysis allowed the exclusion of areas where gullies were less likely to be present. The remaining gully sensitive areas were then manually mapped by using Google Earth, assisting in the creation of a predictive map. A semi-quantitative gully presence map was also created by visually inspecting imagery at $5 \mathrm{~km}$ x $5 \mathrm{~km}$ grid cell scale. Results show a strong relationship between gully presence and drainage features, low tree cover and low slopes. The resulting predictive map has correctly allocated more than $90 \%$ of gullies within less than $20 \%$ of the Burdekin's area, yet uncertainties still remain. The manually derived mapping product comprises the most comprehensive gully data available for the Burdekin, while the high-resolution predictive map and the $5 \mathrm{~km} \times 5 \mathrm{~km}$ grid map will allow better targeting of gullied areas in later stages of this research. This study also provides a methodology that can be applied to mapping gullies over extensive areas. It demonstrates how Google Earth could be used as a reliable platform for mapping gullies and discusses the limitations in the use of remotely sensed data for gully mapping and modelling.
\end{abstract}

\section{INTODUCTION}

Until recently, hillslope erosion was thought to be the dominant contributor of sediments to the Great Barrier Reef (GBR). However, recent work is challenging this assumption, with suggestions that in some subcatchments most of the sediment load is being derived from gully erosion (Bartley et al., 2007). Evidence also suggests that fine sediment particles are of most concern to reef water quality and significant amounts of these are derived from gullies. Consequently, it is important to know where gullies occur in the contributing catchments, as well as to identify the types of landscapes and environmental factors that are associated with gully formation. In the last few years efforts have focused on the Burdekin Catchment $\left(130,000 \mathrm{~km}^{2}\right)$, the fifth largest river catchment in Australia (Bartley et al., 2007) which is the largest contributor of sediments to the Reef. The Remote Sensing Centre of the Queensland Department of Environment and Resource Management, supported by the QScape program, has been undertaking this study aiming to identify the location of gullies and the environmental conditions associated with gully formation in the Burdekin Catchment.

\section{STUDY AREA}

The Burdekin Catchment in central Queensland, Australia, covers $130,000 \mathrm{~km}^{2}$ consisting of almost a third of the total Reef drainage area (Figure 1). The climate of the Burdekin is defined as dry-tropical, ranging between $500-1500 \mathrm{~mm}$ a year (Dight, 2009). The most prevalent land use is grazing which accounts for about $90 \%$ of the sediments and nutrients exported to the reef (Brodie et al., 2003). At the heart of the catchment is the Burdekin Falls Dam which captures about $60 \%$ of the sediments that reach the Lake Dalrymple during flood events (Bainbridge et al., 2008). The dam's location and ability to trap sediments reduces the volume of sediments that arrive from above the dam to only about $20 \%$ of the total sediment load that is exported from the catchment. The remaining $80 \%$ of the load is being transported from the river systems below the dam, in particular the Bowen and Broken rivers (Figure 1).

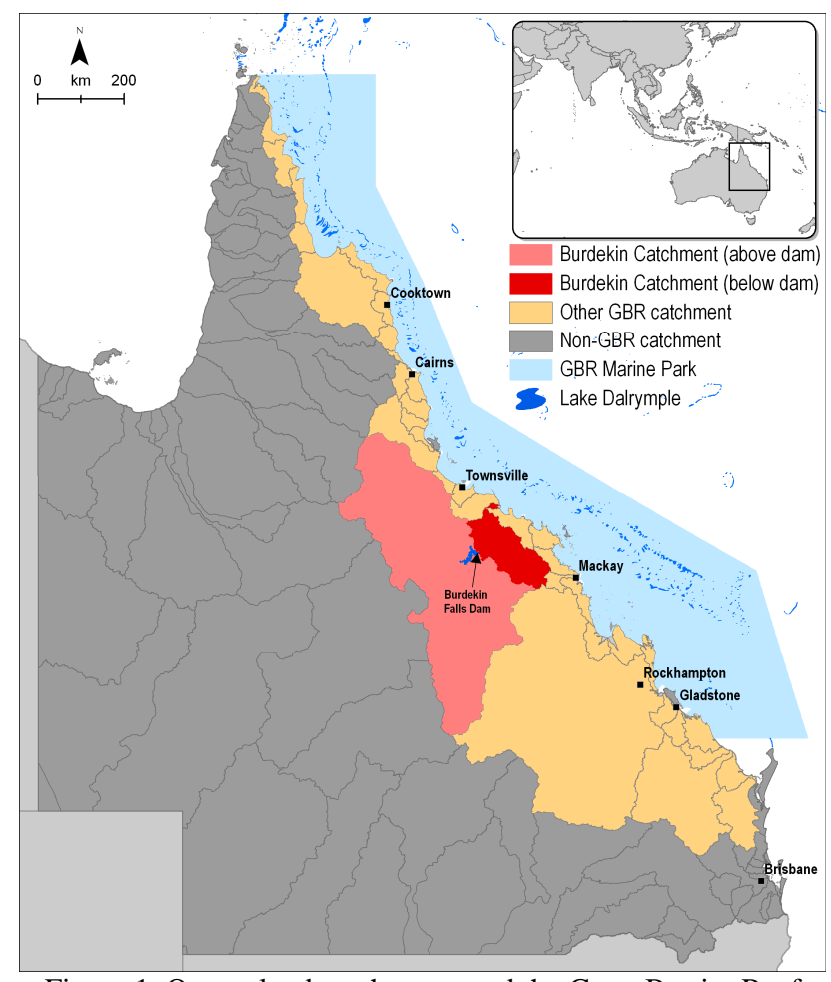

Figure 1. Queensland catchments and the Great Barrier Reef Marine Park boundary. 


\section{DATA AND METHODS}

Google Earth was used to examine the occurrence of gullies in randomly selected sites, and also as a tool for mapping gully extents. This data was then imported into a GIS and examined against several raster and vector data layers representing various landscape variables such as slope (derived from SRTM DEM), Foliage Projective Cover (FPC) (Armston et al., 2009), land clearing (Muir et al., 2011), 1:100,000 vector drainage line, geology, soils, and regional ecosystems (DSEWPC, 2011).

Imagery on Google Earth enabled the identification of gullies; however, this was only possible over about a third of the Burdekin where Google Earth has Quickbird imagery coverage ( $<1 \mathrm{~m}$ pixel resolution). In the remaining $70 \%$ SPOT imagery ( $\sim 2.5 \mathrm{~m}$ pixel resolution) was found not to have sufficient resolution to identify gullies with high certainty (Figure 2).

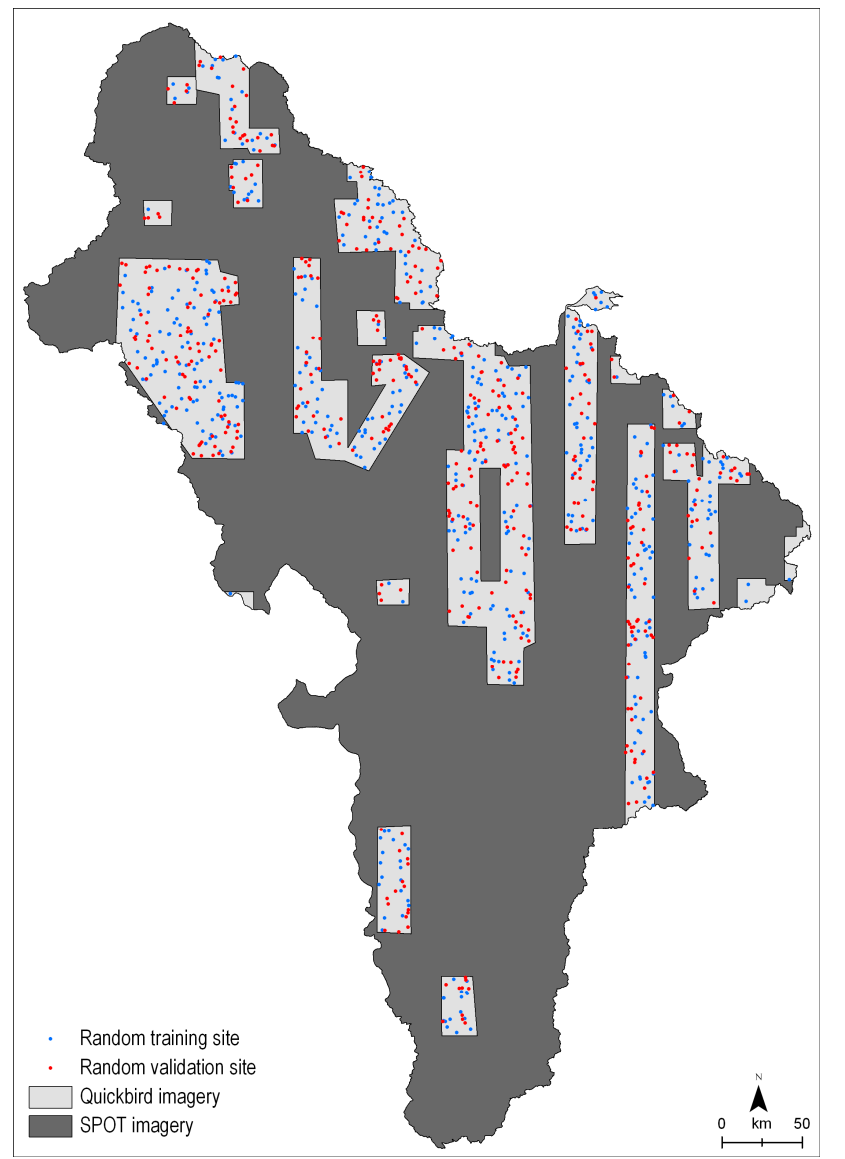

Figure 2. Google Earth imagery coverage and training and validation sites.

Five hundred and eighty two training sites (circle, 28.3 ha each) were randomly generated for areas in the Burdekin where Quickbird or GeoEye imagery were available on Google Earth (Figure 2). Sites were visually inspected on the imagery for the presence or absence of gullies. 104 training sites had gullies present, 433 training sites had no evidence of gullies or gullies were not visible. Forty five training sites were removed from the data set as determination of presence or absence was uncertain due to vegetation or similarity to other erosion features.

Landscape variables were recorded at each gullied site to create a set of conditional classes representing the probability of gullies. Further assumptions were made about presence or absence of gullies based on information provided by local experts and further visual inspection of imagery and field observations. These conditions were then applied across the Burdekin to create a binary map of no-gully areas and gully sensitive areas.

Validation of the results was undertaken by field observation, expert local knowledge and the examination of a further 456 validation sites ( 0.25 ha squares) on Google Earth (Figure 2). The validation sites were smaller than the training sites in order to prevent gully overestimation. This is believed to have been the case with the training sites as these were classified as 'gully' even if gullies composed only a small portion of their area. In line with this assumption, gullies were identified on only 12 validation sites whereas 444 validation sites had no gullies or gullies were not visible.

Knowledge of no-gully areas allowed targeted mapping on areas where gullies are more likely to occur. The mapping (Figure 3) was conducted in the form of manual digitizing on Quickbird imagery on Google Earth using the polygon tool and then importing vectors into ArcGIS. Overall, more than 5100 gullies were digitized over an area of more than $3500 \mathrm{~km}^{2}$. These data were used to validate and further refine the abilities to locate gullies within the gully sensitive area.

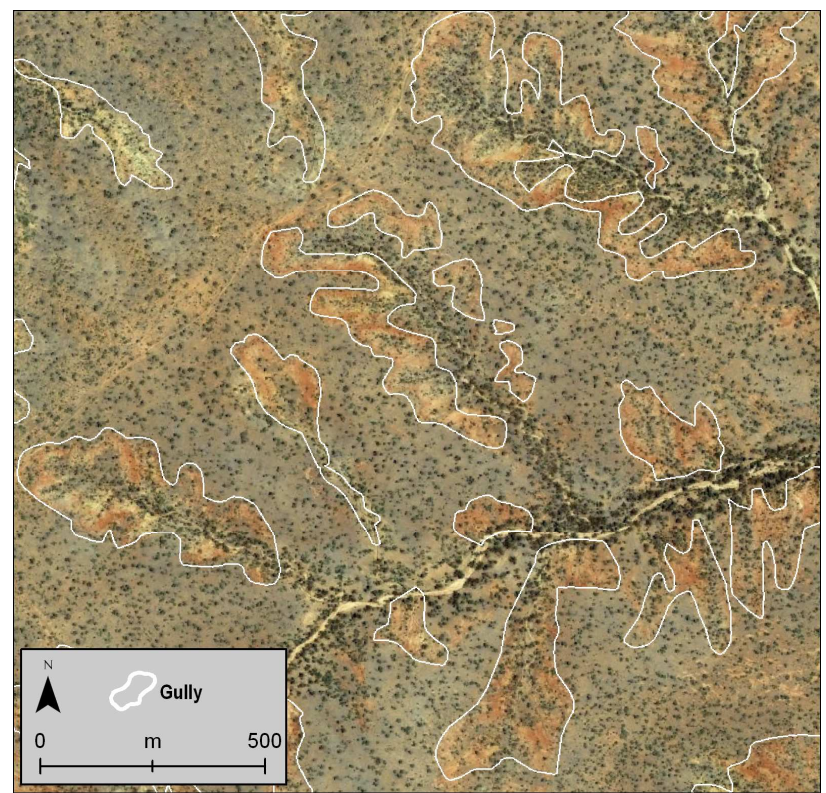

Figure 3. Gully mapping - a sample of a severely gullied area. White polygons indicate gullies. All other areas classified as having no gullies. Background imagery from Google Earth.

The 5100 mapped gullies were then used as training data to examine a group of additional potential explanatory topographic variables derived from the SRTM 1" DEM ( 30 m spatial resolution). The efficiency of the explanatory variables in predicting gully occurrence was assessed by calculating the Area Under the Curve (AUC). The AUC provides an effective measure of how much of the response variables distribution (in this case gully presence) is explained by a particular explanatory variable. Most variables offered a higher than random, yet still modest gully prediction ability (AUC $60-70 \%$, compared with AUC of $50 \%$ for a random prediction). A further test using a multivariate logistic regression model combining several layers did not show significantly improved results. The variable that showed highest correlation with gully occurrence was elevation above drainage line, which had an AUC of $80 \%$ 
(Figure 4). We therefore based the predictive model on probability values based on elevation above drainage line in areas that were initially classified as gully-sensitive areas.

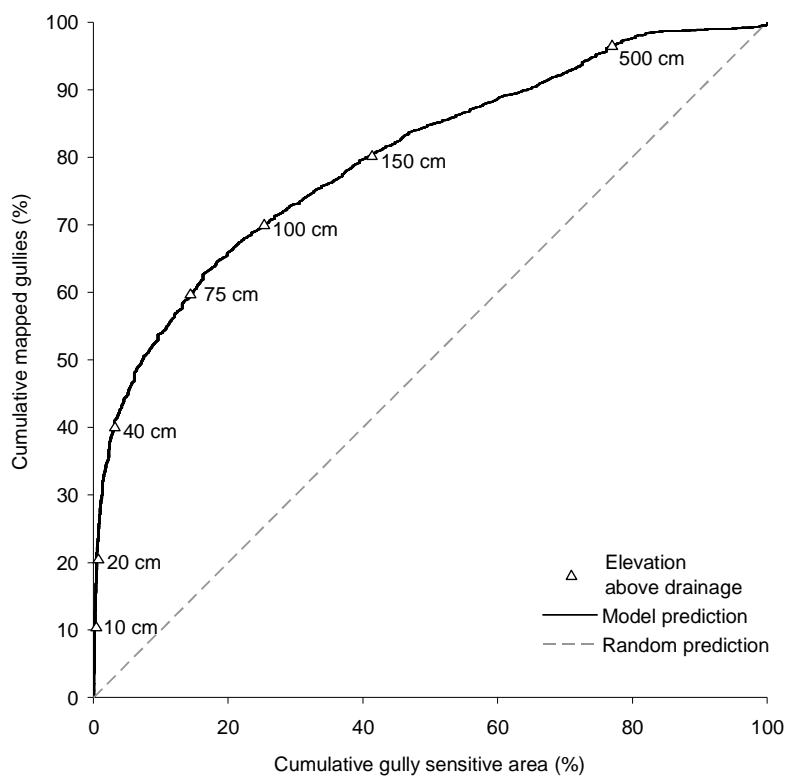

Figure 4. Area Under Curve (AUC) representing the relationship between gully occurrence and elevation above drainage line in gully sensitive areas. Triangles indicate elevation above drainage line. A random prediction (dashed line) is expected to be linear throughout the examined area and therefore would have an AUC of 50\%. The model (solid line) shows an AUC of $80 \%$. This means that elevation above drainage line is explaining the distribution of most of the mapped gullies in a smaller area providing improved prediction ability. For example, the model locates $60 \%$ of the gullies within only $15 \%$ of the gully sensitive area closest to drainage line $(<75 \mathrm{~cm})$.

A final, comprehensive broad-scale semi-quantitative gully presence map gully was developed. The Burdekin was divided into 5521 cells of $5 \mathrm{~km} \times 5 \mathrm{~km}$. Each cell was assigned with one of seven gully presence values ranging from very low to very high. The gully presence values were determined by several methods. Where available, values were assigned based on observations from high resolution imagery. At locations without high resolution imagery, the gully presence values were assigned based on results of statistical analysis, which examined the values in the already assigned cells against (i) the extent of no-gully area within each cell; or (ii) the association of a cell with a sub-bioregion (DSEWPC 2011) where most observations were assigned as low gully value; or (iii) information from the predictive model. The final map provides a gully presence value for each $5 \mathrm{~km} \times 5 \mathrm{~km}$ grid cell in the Burdekin with various confidence levels relating to the above methods used to determine these values (Figure 5).

\section{RESULTS}

Initial results showed that areas at a distance greater than $300 \mathrm{~m}$ from a drainage line, or with high tree cover (FPC above 30\%), or with high slopes (above $10^{\circ}$ ) or on basaltic geology had extremely low probability of gully occurrence (Table 1). Based on these relationships, the Burdekin was divided into two areas: A no-gully area, which covers $47 \%$ of the Burdekin and where less than $7 \%$ of the gullies occur; and a gully sensitive area, which covers $53 \%$ of the Burdekin and where more than $93 \%$ of gullies occur (Figure 6). By combining the no-gully area with the elevation above drainage line layer a $30 \mathrm{~m}$ resolution gully predictive model was produced that has predicted more than $90 \%$ of the mapped gullies within less than $20 \%$ of the total Burdekin area (Figure 7).

The gully presence map provides a regional view of gully extent (Figure 8). Overall, several areas were identified as gully 'hotspots'. The most affected areas are in the south of the Upper Burdekin subcatchment, the northern part of the Suttor subcatchment and the Bowen Broken Bogie subcatchment. These results allow for better targeting of gully research in later stages of this research, where gully expansion rates and sediment volumes will be examined.

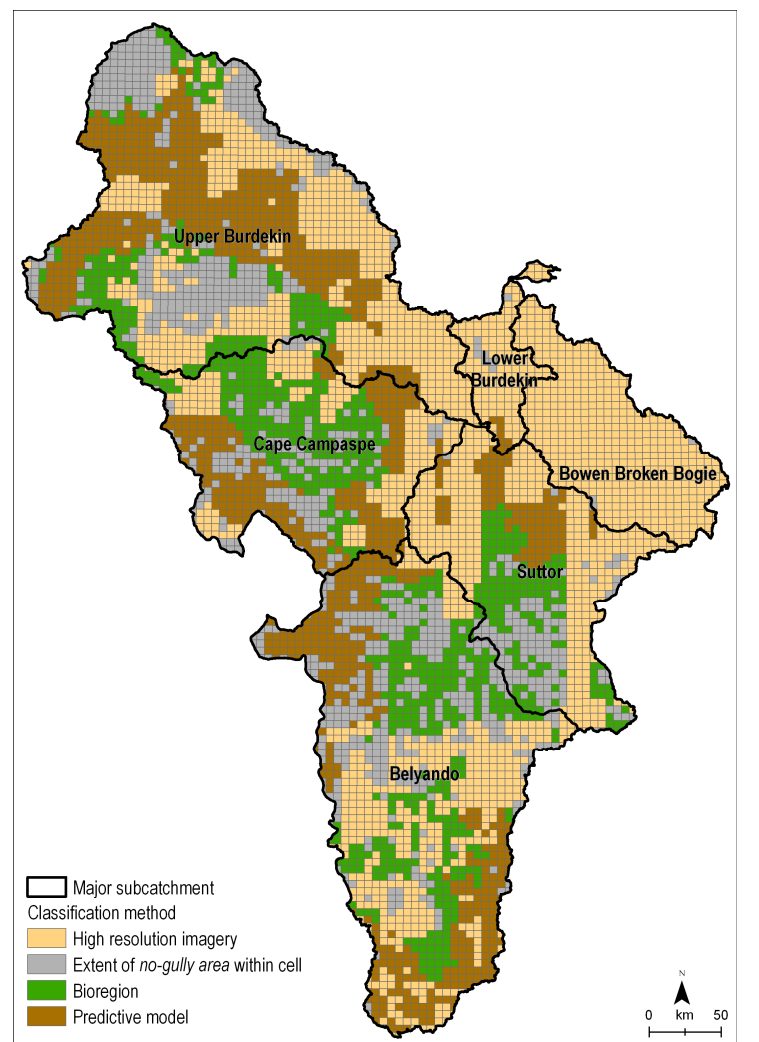

Figure 5. Classification methods for gully values for the gully presence map.

\begin{tabular}{|c|c|c|c|c|}
\hline Class & $\begin{array}{c}\text { Landscape } \\
\text { description }\end{array}$ & $\begin{array}{c}\text { Gullied } \\
\text { training } \\
\text { sites }\end{array}$ & $\begin{array}{c}\text { Gullied } \\
\text { validation } \\
\text { sites }\end{array}$ & $\begin{array}{c}\% \text { of } \\
\text { total } \\
\text { area }\end{array}$ \\
\hline $\begin{array}{c}\text { Gully } \\
\text { sensitive } \\
\text { area }\end{array}$ & $\begin{array}{c}<600 \mathrm{~m} \text { from } \\
\text { drainage line, } \\
\text { or FPC }<30 \%, \\
\text { or slope }>10^{\circ}\end{array}$ & $93 \%$ & $100 \%$ & $53 \%$ \\
\hline $\begin{array}{c}\text { No-gully } \\
\text { area }\end{array}$ & $\begin{array}{c}>600 \mathrm{~m} \text { from } \\
\text { drainage line, } \\
\text { or FPC }>30 \%, \\
\text { or slope }>10^{\circ}, \\
\text { or basaltic } \\
\text { soil }\end{array}$ & $7 \%$ & $0 \%$ & $47 \%$ \\
\hline
\end{tabular}

Table 1. Classification of the Burdekin into no-gully and gully sensitive areas according to gully occurrence at various landscapes. 


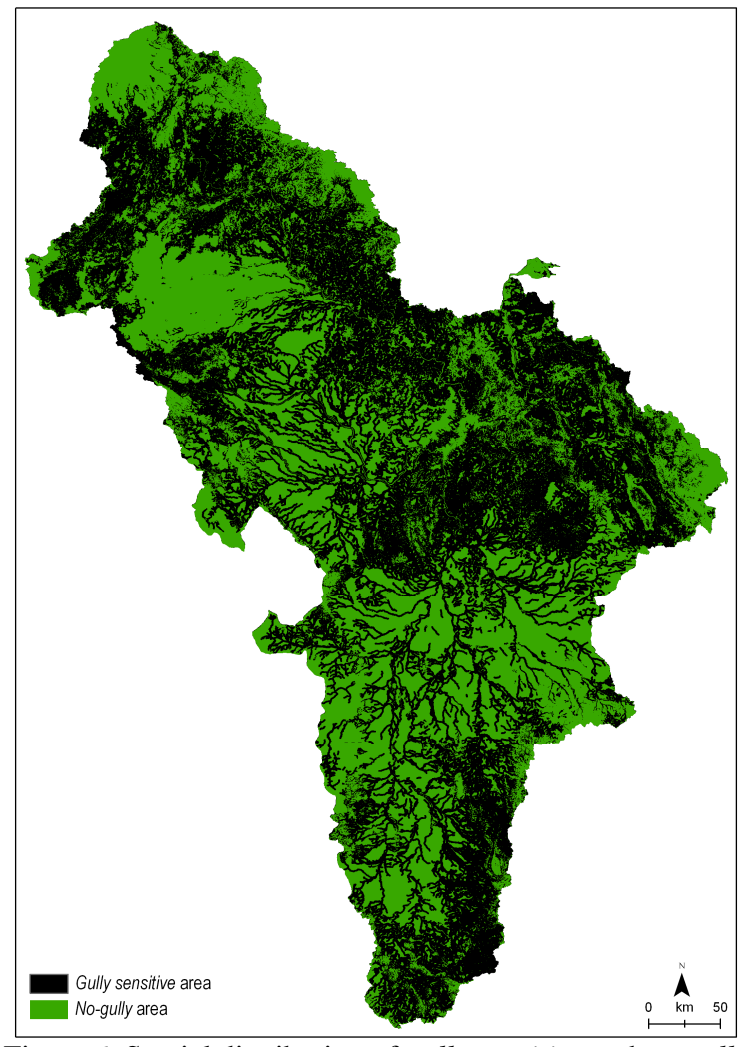

Figure 6. Spatial distribution of gully sensitive and no-gully areas.

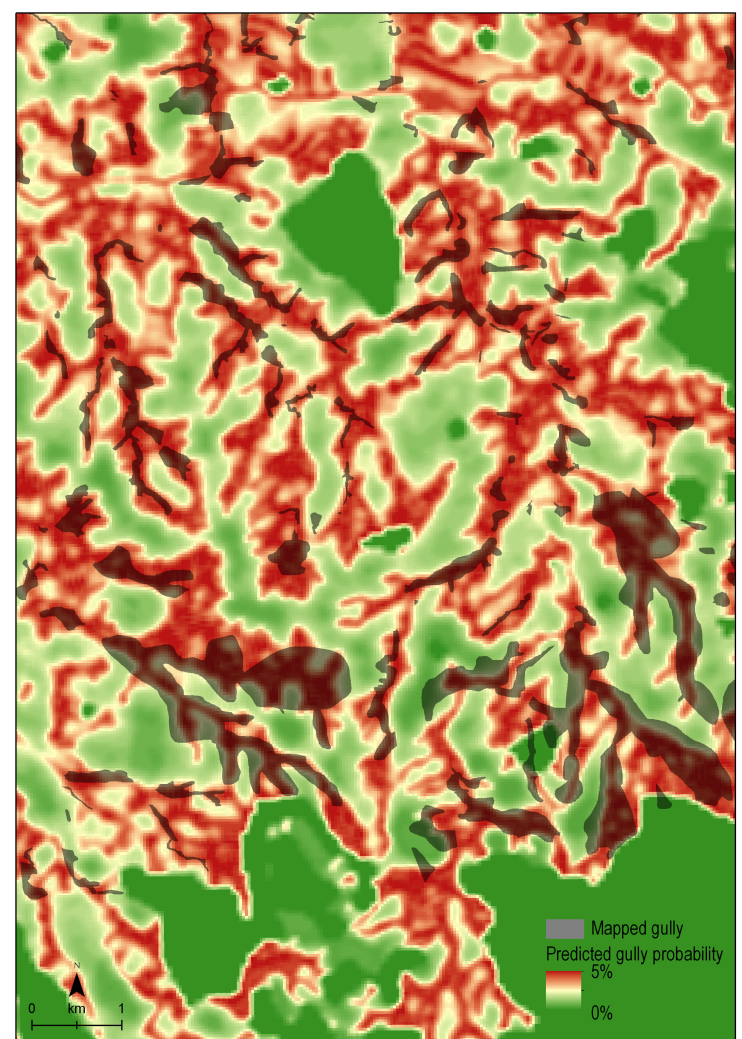

Figure 7. Model prediction vs. actual mapped gullies. Dark green is no-gully area. Gullies rarely occur on low probability areas; however, prediction within high probability areas still needs to be refined.

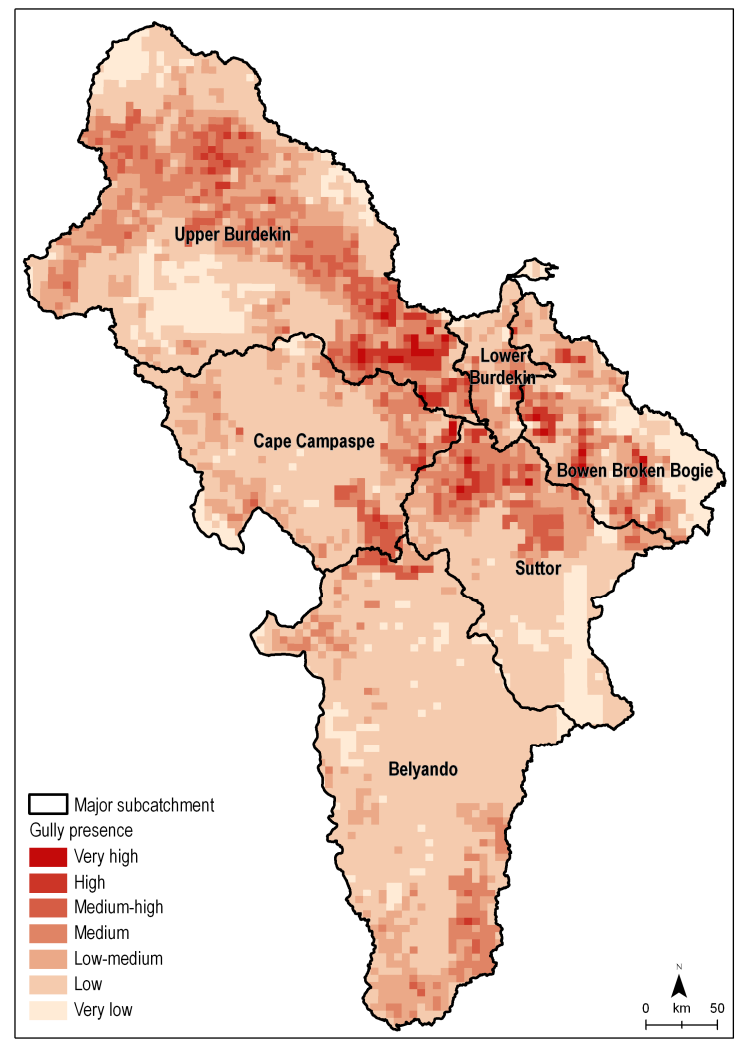

Figure 8. Gully presence map. Extensive gullying in several areas mainly in the Upper Burdekin, northern Suttor and Bowen Broken Bogie subcatchments.

\section{DISCUSSION AND CONCLUSIONS}

This study provides a metholodogy that could be applied to extensive areas where the mapping of all individual gullies is not feasible. For such large areas, it is important to first acknowledge the importance of identifying areas where gullies are less likely to occur. The no-gully area in the Burdekin covered an area of more than $61,000 \mathrm{~km}^{2}$ - this is an area twice the size of Belgium that could now be omitted from further analysis. Identifying the no-gully area allowed better targeting of gullied areas for mapping and could be used in the future for gully modelling as well as policy-making and land management purposes.

Analysis of observed cells in the gully presence map against extents of no-gully areas showed that the latter are in fact gully free. In the predictive model, most of the uncertainty still remains in the high probability areas. Although these cover only about $20 \%$ of the Burdekin, gullies only occur at a fraction of this area. Consequently, we can assume the low probability prediction to be relatively accurate, yet further refinement of the prediction ability is needed before the same could be assumed for the high probability areas.

With the increasing availability of high-resolution data it is now easier to visually identify gullies. Google Earth has proven to be a reliable platform for mapping gullies as it holds highresolution data while allowing fast browsing coupled with digitization tools that can be easily exported back to the local GIS. Nevertheless, similarly to previous works (Eustace et al., 2011; Prosser et al., 2002), this study shows that remote sensing product such as imagery or DEM products can only go so far 
when it comes to prediction or automated mapping of gully occurrence. These difficulties arise from the variability in factors that contribute to gully occurrence; the complex shapes, size and forms of gullies; and the lack of access or ability to obtain additional high-resolution data that might be useful, such as grazing pressure or high resolution soil maps. Considering the current limitations the best approach would be to invest more time and efforts in hands-on, pragmatic approaches based on observations and field data rather than predictive modelling, which could be used as a last option to fill gaps at locations of low certainty.

\section{REFERENCE}

Armston, J.D., Denham, R.J., Danaher, T.J., Scarth, P.F., Moffiet, T.N., 2009. Prediction and validation of foliage projective cover from Landsat-5 TM and Landsat-7 ETM+ Imagery. Journal of Applied Remote Sensing, 3:033540.

Bainbridge, Z., Lewis, S., Davis, A., Brodie, J., 2008. Eventbased community water quality monitoring in the Burdekin Dry Tropics NRM Region: 2007/08 wet season update. ACTFR report number 08/19. Townsville, Australia.

Bartley, R., Hawdon, A., Post, D.A., Roth, C.H., 2007. A sediment budget for a grazed semi-arid catchment in the Burdekin basin, Australia. Geomorphology, 87 (4), pp. 302-321.
Brodie, J., McKergow, L.A., Prosser, I.P., Furnas, M., Hughes, A.O., Hunter, H., 2003. Sources of Sediment and Nutrient Exports to the Great Barrier Reef World Heritage Area. ACTFR report number 03/11. Townsville, Australia.

Dight, I., 2009. Burdekin Water Quality Improvement Plan. NQ Dry Tropics, Townsville, Australia.

DSEWPC (Department of Sustainability, Environment, Water, Population and Communities), 2011. Australia's bioregions, http://www.environment.gov.au/parks/nrs/science/bioregionframework/index.html (12 Jan. 2011).

Eustace, A.H., Pringle, M.J., Denham, R.J., 2011. A risk map for gully locations in central Queensland, Australia. European Journal of Soil Science 62 (3), pp. 431-441.

Muir, J., Schmidt, M., Tindall, D., Travithick, R., Scarth, P., Stewart, J., 2011. Field measurement of fractional ground cover: A technical handbook supporting ground cover monitoring for Australia. Australian Bureau of Agricultural and Resource Economics and Sciences. Canberra, Australia.

Prosser, I., Moran, C., Lu, H., Scott, A., Rustomji, P., Stevenson, J., et al., 2002. Regional Patterns of Erosion and Sediment Transport in the Burdekin River Catchment. CSIRO Land and Water Technical Report 5/02. Canberra, Australia. 